\title{
Evaluation of Analgesic Property of Petroleum Ether/Ethyl Acetate Stem Bark Extract and Fractions of Maerua angolensi s in Murine Models of Pain
}

\author{
Hosea Azi Iliya ${ }^{1,2 *}$, Eric Woode ${ }^{2}$ \\ ${ }^{1}$ Department of Pharmacology, University of Jos, Jos, Nigeria. ${ }^{2}$ Department of Pharmacology, Faculty of Pharmacy and Pharmaceutical Sciences, Kwame \\ Nkrumah University of Science and Technology, Kumasi, Ghana.
}

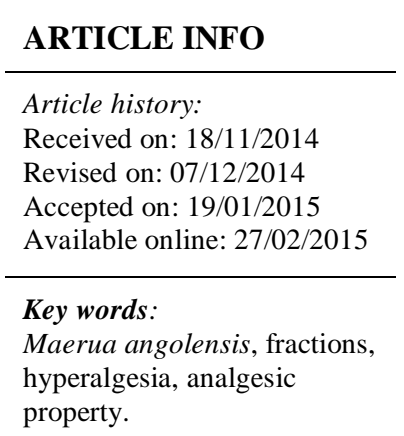

\begin{abstract}
This study investigated the possible antinociceptive action of the petroleum ether/ethyl acetate extract and fractions prepared from the stem barks of Maerua angolensis. The acetic acid-induced abdominal writhing, formalin-induced nociception, prostaglandin $\mathrm{E}_{2}$-induced mechanical hyperalgesia, bradykinin- and epinephrineinduced thermal hyperalgesia tests as well as Paw withdrawal test using Hargreaves thermal hyperalgesia model were used to assess the antinociceptive effects of the extract and the fractions after oral administration in rodents. Diclofenac and morphine were used as reference analgesic agents. Mice were submitted to the rotarod test in order to assess any non-specific muscle-relaxant effect of the extract and the fractions. The petroleum ether/ethyl acetate extract and the fractions of Maerua angolensis produced significant $(P<0.05)$ and dose-dependent antinociceptive effects in the acetic acid, formalin, prostaglandin $E_{2}$, bradykinin, epinephrine and paw withdrawal tests. The extract and the fractions of Maerua angolensis ( 3 and $10 \mathrm{mg} / \mathrm{kg}$ ) did not compromise the motor coordination of animals in the rotarod test, suggesting lack of central depressant effect. The petroleum ether/ethyl acetate extract and fractions of Maerua angolensis stem bark produced dose-dependent antinociception in murine models of chemical, mechanical and thermal nociception suggesting peripheral and central analgesic action.
\end{abstract}

\section{INTRODUCTION}

Pain is a disabling supplement of many medical conditions worldwide (Schim and Stang, 2004). It is the major cause of all first visits to hospitals for consultations and the most common symptom of disease or injury (Porth, 2011). In many pathological conditions particularly, cancer, HIV/AIDS, sickle cell disease and diabetes, the management of pain remains a cause for concern. The use of opioids and non-steroidal antiinflammatory drugs (NSAIDs) are associated with side effects such as gastric ulcerations and tolerance coupled with the fact that they are not effective in neuropathic pain. This has necessitates the need to search for potent and safe analgesics

\footnotetext{
* Corresponding Author

Hosea Azi Iliya, Department of Pharmacology,

University of Jos, Jos, Nigeria.Email: hoseaazi@yahoo.com

Email:hoseaazi@yahoo.com
}

from medicinal plants which are known to have a long history of use in traditional medicine. The validation of traditional claims of these medicinal plants will provide scientific basis for the conservation of tropical medicinal resources that are going on extinct, the deployment of the beneficial ones as phytomedicines in the primary health care and the development of potential bioactive constituents. These could provide novel compounds or precursors in drug development and utilization of isolated compounds as research tools in drug development. Maerua angolensis (synonyms Maerua arenicola) of the family Capparidaceae is one of such medicinal plants reputed for its wide ethno medicinal use including psychosis, epilepsy, diabetes, stomach ulcer, hepatitis and various painful conditions in some West African countries (Mothana et al., 2009, Meda et al., 2013, Okatch et al., 2012, Iliya et al., 2014, Magaji et al., 2008, Mohammed et al., 2008). It is widespread in the Savannah area of tropical Africa, commonly found growing in bush and rocky areas. 
Phytochemical tests of the methanolic stem bark extract has shown the presence of saponins, steroids, terpenoids, tannins, flavonoids, alkaloids and glycosides (Adamu et al., 2007, Magaji et al., 2009). Information on the median lethal dose $\left(\mathrm{LD}_{50}\right)$ of the stem bark extract of the plant in mice revealed $\mathrm{LD}_{50}$ of $3,807.9$ $\mathrm{mg} / \mathrm{kg}$ orally (p.o.) and greater than $500 \mathrm{mg} / \mathrm{kg}$ intraperitoneally (i.p.) (Magaji et al., 2008) suggesting relative safety of the stem bark.

The antinociceptive property of the stem bark, the most active plant part, in various solvents has been demonstrated in writhing and formalin tests (Iliya et al., 2014). The aim of this study is to evaluate the analgesic property of petroleum ether/ethyl acetate extract and fractions prepared from the stem barks of Maerua angolensis in different assays of the chemical, mechanical and thermal models of nociception in rodents.

\section{MATERIALS AND METHODS}

\section{Plant materials}

Fresh stem barks of Maerua angolensis were collected from the Samaru campus of Ahmadu Bello University, Zaria, Nigeria in August, 2012. The stem barks were identified at Department of Herbal Medicine, Faculty of Pharmacy and Pharmaceutical Sciences, Kwame Nkrumah University of Science and Technology (KNUST), Kumasi, Ghana, by Dr. Kofi Annan. A voucher specimen (KNUST/FP/12/051) was kept at the herbarium of the Faculty.

\section{Animals}

Sprague-Dawley rats $(190-200 \mathrm{~g})$ and ICR mice $(20-$ $25 \mathrm{~g}$ ) of either sex were used after approval of protocol for the study by the local ethical committee for animal handling and experimental procedure. All animals were housed in groups of five in stainless steel cages ( 34 x 47 x $18 \mathrm{~cm}$ ) with softwood shavings as bedding in the animal facility of the Department, KNUST, with free access to food and water and were maintained under normal laboratory conditions of humidity, temperature $\left(25 \pm 1{ }^{0} \mathrm{C}\right)$ and a $12 \mathrm{~h} / 12 \mathrm{~h}$ day/night cycle. Each animal was used only once. The investigation conforms to the Guide for the Care and Use of Laboratory Animal published by the US National Institutes of Health (NIH No. 85 - 23, revised 1996). In all the experimental studies each group consisted of 5 animals.

\section{Drugs and chemicals}

The following drugs and chemicals were used: Acetic acid, carrageenan sulphate and formalin (BDH, Poole, England), diclofenac sodium (Troge Medical GmbH, Hamburg, Germany), morphine hydrochloride (Phyto-Riker, Accra, Ghana), prostaglandin $\mathrm{E}_{2}$ and bradykinin acetate (Sigma-Aldrich Inc., St. Louis, MO, USA), epinephrine hydrochloride (Wuhan Grand Pharm, China), atenolol (Ernest Chemist Ltd, Accra, Ghana), captopril (Teva UK Ltd, Eastbourne, UK). All drugs used in the nociceptive tests were dissolved in normal saline.

\section{Extraction and fractionation}

For the preparation of the petroleum ether/ethyl acetate extract of Maerua angolensis, the procedure used by Iliya (Iliya et al., 2014) was employed. $4 \mathrm{~kg}$ of dried and powdered stem barks was sequentially extracted for 4 days with $10 \mathrm{~L}$ of petroleum ether and $10 \mathrm{~L}$ of ethyl acetate by cold maceration. The materials were filtered and the filtrates concentrated separately in a rotary evaporator under reduced temperature and pressure to give yellowish syrupy mass. These were dried in the oven (Gallenhamp ${ }^{\circledR}$, England) at $50{ }^{0} \mathrm{C}$ to obtain yields of 2.23 and $3.87 \%(\mathrm{w} / \mathrm{w})$ respectively. The thin layer chromatography (TLC) profile of the petroleum ether stem bark extract and the ethyl acetate stem bark extract on aluminium sheet pre-coated with normal phase silica gel eluted with petroleum ether/chloroform (90:10) were found to be similar indicating similar constituents thus the two extracts were combined and subsequently referred to as Maerua angolensis stem bark extract (MAE). The MAE (10 g) was fractionated using the chromatography column technique in which silica gel $60 \mathrm{~F}_{254}$ (Merck, $0.20 \mathrm{~mm}$ thickness) was used as adsorbent and elution effected using the solvents petroleum ether (100\%), petroleum ether/ethyl acetate (90:10), and petroleum ether/ethyl acetate (50:50) sequentially in order of increase in polarity. A total of 64 fractions were collected in $100 \mathrm{ml}$ aliquots. Continuous elution with $100 \%$ petroleum ether yielded 31 fractions (fractions 1 - 31). Further elution with petroleum ether and ethyl acetate (90:10) yielded 24 fractions (fractions $32-55$ ) while 9 fractions (fractions 56 - 64) resulted from continuous elution with petroleum ether and ethyl acetate (50:50). Fractions with similar TLC profiles indicating similar phytochemical constituents were combined and concentrated. Fractions $1-2$ were combined giving a yield of $5.5 \%(\mathrm{w} / \mathrm{w})$ and coded $\mathrm{F} 1$ while fractions $32-34$ were combined giving a yield of $6.7 \%(\mathrm{w} / \mathrm{w})$ and coded F32.

\section{Evaluation of the analgesic effect of Maerua angolensis extract and fractions in writhing test}

The petroleum ether/ethyl acetate extract of Maerua angolensis (MAE), the fractions (F1, F32) (3, 10 and $30 \mathrm{mg} / \mathrm{kg}$, p.o.), diclofenac sodium (reference analgesic agent) (3, 10 and 30 $\mathrm{mg} / \mathrm{kg}$, i.p.) or normal saline (control) $(10 \mathrm{ml} / \mathrm{kg}$, i.p.) were administered to groups of mice. Acetic acid $(0.6 \% \mathrm{v} / \mathrm{v})$ was given (10 $\mathrm{ml} / \mathrm{kg}$, i.p.) $1 \mathrm{~h}$ after the oral and $30 \mathrm{~min}$ after the intraperitoneal administration to all mice. The number of abdominal constrictions (writhes) per $5 \mathrm{~min}$ segments for $30 \mathrm{~min}$ was counted $5 \mathrm{~min}$ after acetic acid injection. A significant reduction in the number of acetic acid-induced abdominal constrictions by any treatment compared with control treated mice was considered as an antinociceptive response (Taïwe et al., 2011, Sikdar et al., 2013).

\section{Evaluation of the analgesic effect of Maerua angolensis fractions in formalin test}

The formalin test was carried out as described by Tjolsen (Tjølsen et al., 1992) and Fischer (Fischer et al., 2013). Rats were 
given F1, F32 (3 - $30 \mathrm{mg} / \mathrm{kg}$, p.o.), morphine hydrochloride (reference analgesic agent) $(0.3,1$ and $3 \mathrm{mg} / \mathrm{kg}$, i.p.) or normal saline $(10 \mathrm{ml} / \mathrm{kg}$, i.p.). Formalin $(5 \%)$ was given by intraplantar injection $(10 \mu \mathrm{l})$ in the right hind paw $1 \mathrm{~h}$ after the oral and $30 \mathrm{~min}$ after the intraperitoneal administration to all rats to induce pain $(\mathrm{J}$ Cobos and Portillo-Salido, 2013). The amount of time spent licking/biting the injected paw was measured and taken as an indication of pain (Woode et al., 2009). Pain response per $5 \mathrm{~min}$ segments for $1 \mathrm{~h}$ was scored starting immediately after formalin injection. Average nociceptive score for each time block was determined as product of frequency and time spent in licking/biting the injected paw. The first phase of the nociceptive response normally peaks $0-5 \mathrm{~min}$ and the second phase $15-30$ min after formalin injection corresponding to the neurogenic and inflammatory pain responses respectively (Hunskaar and Hole, 1987, Godínez-Chaparro et al., 2013).

\section{Evaluation of the analgesic effect of Maerua angolensis extract and fractions in prostaglandin $E_{2}$-induced mechanical hyperalgesia}

The method is a version of that described previously (Woode et al., 2013, Wilhelm et al., 2009). After baseline pain threshold measurements, male rats received MAE, F1, F32 (3 - 30 $\mathrm{mg} / \mathrm{kg}$, p.o.), morphine $(0.3-3 \mathrm{mg} / \mathrm{kg}$, i.p.) or normal saline (10 $\mathrm{ml} / \mathrm{kg}$, i.p.) $1 \mathrm{~h}$ (for the oral route) or $30 \mathrm{~min}$ (for the intraperitoneal route) before the intraplantar injection of prostaglandin $\mathrm{E}_{2}(1 \mathrm{nmol} / \mathrm{paw})$. Mechanical nociceptive thresholds were determined in the rat paw pressure test using an analgesimeter (Model No. 15776, Ugo Basile, Comerio, Varese, Italy) which is based on the Randall and Selitto method (Randall and Selitto, 1957, Tanabe et al., 2005). The analgesimeter was used to apply a linearly-increasing pressure, by means of a blunt Perspex cone, to the dorsal region of the right hind paw of the rat until the rat squealed, struggled or withdrew the paw. Rats received two training sessions before the day of testing. An hour after prostaglandin $\mathrm{E}_{2}$ administration, pressure was gradually applied to the right hind paw at a constant rate and paw withdrawal thresholds (PWTs) were assessed as the pressure (grams) that elicits paw withdrawal. PWTs were measured again at $30 \mathrm{~min}$ intervals for 2 hours. A cut-off point of $250 \mathrm{~g}$ was chosen as the maximum weight to apply to prevent any tissue damage to the paw of the rats. Antihyperalgesic effects exerted by drugs were calculated from the PWTs as a percentage of the maximum possible effect (\% MPE).

\section{Evaluation of the analgesic effect of Maerua angolensis extract and fractions in bradykinin-induced thermal hyperalgesia}

After baseline paw withdrawal latencies (PWLs) measurements, male rats were pretreated with MAE, F1, F32 (3 $30 \mathrm{mg} / \mathrm{kg}$, p.o.) or normal saline $(10 \mathrm{ml} / \mathrm{kg}$, i.p.) $1 \mathrm{~h}$ (for the oral route) or $30 \mathrm{~min}$ (for the intraperitoneal route) before the intraplantar injection of bradykinin (10 nmol/paw). Rats were pretreated with captopril ( $5 \mathrm{mg} / \mathrm{kg}$, subcutaneously) $1 \mathrm{~h}$ before experiments to prevent the degradation of bradykinin. Thermal nociceptive latencies were measured in the rat paw by means of radiant heat source using the IITC Model 336 Paw/Tail stimulator Analgesia Meter (Woodland Hills, CA., USA) (Galbraith et al., 1993, Fecho et al., 2005, Tanabe et al., 2005). The rats were individually placed in a transparent plexi glass observation chamber on a clear glass platform for acclimatization period of 15 min to the testing environment. The test head of the paw stimulator was used to present a focused beam of radiant light on to the mid plantar region of the right hind paws. The thermal nociceptive stimulus was manually directed under the foot pad before drug administration, and at $1,1.5,2,2.5$, and $3 \mathrm{~h}$ post drug administration into the right hind paw. A timer was set to automatically turn off the light source when the rat withdrew the paw, and the PWLs (time required for the paw to show an abrupt withdrawal) measured. Rats received two training sessions before the day of testing. A cut-off time of $25 \mathrm{~s}$ was chosen as the maximum time to prevent any tissue damage to the paw. Antihyperalgesic effects exerted by drugs were calculated from the PWLs as \% MPE.

Evaluation of the analgesic effect of Maerua angolensis extract and fractions in epinephrine-induced thermal hyperalgesia

After baseline PWLs measurements, rats were pretreated with MAE, F1, F32 (3 - $30 \mathrm{mg} / \mathrm{kg}$, p.o.), atenolol (reference drug) (1, 3 and $10 \mu \mathrm{g} / \mathrm{paw})$ or normal saline $(10 \mathrm{ml} / \mathrm{kg}$, i.p.) $1 \mathrm{~h}$ (for the oral route) or $30 \mathrm{~min}$ (for the intraperitoneal route) before the intraplantar injection of epinephrine (450 nmol/paw). Thermal nociceptive latencies were measured in the rat paw by means of radiant heat source using the IITC Model 336 Paw/Tail stimulator Analgesia Meter (Woodland Hills, CA., USA) (Galbraith et al., 1993, Meotti et al., 2006, Moriyama et al., 2005). The rats were individually placed in a transparent plexi glass observation chamber on a clear glass platform for acclimatization period of 15 min to the testing environment. The test head of the paw stimulator was used to present a focused beam of radiant light on to the mid plantar region of the right hind paws. The thermal nociceptive stimulus was manually directed under the foot pad before drug administration, and at $1,2,3$, and 4 h post drug administration into the right hind paw. A timer was set to automatically turn off the light source when the rat withdrew the paw, and the PWLs measured.

Rats received two training sessions before the day of testing. A cut-off time of $25 \mathrm{~s}$ was chosen as the maximum time the rat's paw will be stimulated with the light in order to prevent any tissue damage to the paw. Antihyperalgesic effects exerted by drugs were calculated from the PWLs as (\% MPE).

\section{Evaluation of the analgesic effect of Maerua angolensis extract and fractions in paw withdrawal test using Hargreaves thermal hyperalgesia model}

Paw withdrawal latencies were determined with the IITC Analgesia Meter (model 336, IITC Life Science Inc., Woodland Hills, CA, USA). Male rats were individually placed in a transparent plexi glass observation chamber on a clear glass 
platform for acclimatization period of $15 \mathrm{~min}$ to the testing environment. A focused beam of radiant light was delivered on to the mid plantar region of the right hind paw until the rat withdrew the paw (Galbraith et al., 1993, Negus et al., 2006). Baseline measurements were taken followed by administration of carrageenan (100 $\mu 1$ of a $2 \%$ solution) into the right hind paw one hour (for the oral route) or $30 \mathrm{~min}$ (for the intraperitoneal route) post treatment with MAE, F1, F32 (3 - $30 \mathrm{mg} / \mathrm{kg}$, p.o.), morphine $(0.3-3 \mathrm{mg} / \mathrm{kg}$, i.p.) or normal saline (10 ml/ $\mathrm{kg}$, i.p.). A timer was set to automatically turn off the light source when the rat withdrew the paw, and PWLs were measured. Two hours after carrageenan injection, PWLs were measured again hourly for 4 hours. A cutoff time of $25 \mathrm{~s}$ was chosen as the maximum time the rat's paw will be stimulated with the light in order to prevent any tissue damage to the paw.

Rats received two training sessions before the day of testing. Antihyperalgesic effects exerted by drugs were calculated from the PWLs as \% MPE.

\section{Evaluation of motor performance in the analgesic effect of Maerua angolensis extract and fractions}

The motor function test using the rotating rod method was performed to determine whether any of the observed antinociceptive effects of Maerua angolensis extract and fractions resulted from sensory blockade or from an impairment of motor function (Gareri et al., 2005, Kondo et al., 2008). Naïve mice were trained for three successive days on the rotarod (Ugo Basile, model 7600 , Comerio, Varese, Italy) at the speed of 25 revolutions per min.

A preliminary selection of mice was made on the previous day of experiment excluding those that did not remain on the rotarod bar during a 2 min session each. On the test day, selected mice (ten groups) were tested $1 \mathrm{~h}$ (for the oral route) or 30 $\min$ (for the intraperitoneal route) after receiving MAE, F1, F32 (3 - $30 \mathrm{mg} / \mathrm{kg}$, p.o.) or normal saline (10 ml/kg, i.p.). The mice were repeatedly tested for their motor coordination performance on the rotarod (cut off time $120 \mathrm{~s}$ ) at $1,2,3$, and $4 \mathrm{~h}$ after drug administration. Impairment of coordinated motor movements was defined as the inability of the mice to remain on the rotarod for a test period of $120 \mathrm{~s}$.

\section{Statistical analysis}

Data were expressed as mean \pm standard error of the mean (SEM) per group. Statistical differences between control and drug treated groups were tested by two-way (treatment $\mathrm{x}$ time) repeated measures analysis of variance (ANOVA) with Bonferroni's post hoc test, differences between other means were by one-way ANOVA followed by Newman-Keuls post hoc test. The $\mathrm{ED}_{50}$ (dose of drug necessary to reduce the response by $50 \%$ relative to the control value) and $95 \%$ confidence intervals values were determined by using nonlinear regression (three-parameter logistic). GraphPad Prism 5.01 for Windows (GraphPad Prism Software, San Diego, CA, USA) was used for all statistical analyses. Differences were considered significant at $\mathrm{P}<0.05$.

\section{RESULTS AND DISCUSSION \\ Evaluation of the analgesic effect of Maerua angolensis extract and fractions in writhing test}

Figure 1 shows the effect of various treatments in writhing test during the $30 \mathrm{~min}$ observation period. MAE, F1, F32 and diclofenac dose-dependently and significantly reduced the time-course curve of acetic acid-induced abdominal constrictions (Figure 1a, c, e and g). Two-way ANOVA (treatment $\mathrm{x}$ time) revealed a significant (MAE: $\mathrm{F}_{3,112}=25.29 ; \mathrm{P}<0.0001, \mathrm{~F} 1: \mathrm{F}_{3,112}=$ 13.55; $P<0.0001, \mathrm{~F} 32: \mathrm{F}_{3,112}=33.08 ; P<0.0001$ and diclofenac: $\mathrm{F}_{3}$, $\left.{ }_{112}=47.43 ; P<0.0001\right)$ effect of drug treatments on the acetic acidinduced abdominal constrictions. MAE; F1 and F32 (3 - 30 $\mathrm{mg} / \mathrm{kg}$, p.o. $1 \mathrm{~h}$ before acetic acid injection) dose-dependently and significantly $\left(\mathrm{F}_{3},{ }_{16}=6.346, P=0.0049 ; \mathrm{F}_{3},{ }_{16}=4.354, P=0.0201\right.$ and $\left.F_{3},{ }_{16}=11.27, P=0.0003\right)$ reduced the number of abdominal writhes over 30 min with maximal inhibition of $89.3 \pm 9.3 \%$; 67.4 $\pm 19.2 \%$ and $78.6 \pm 15.5 \%$ respectively (Figure $1 \mathrm{~b}, \mathrm{~d}$ and $\mathrm{f}$ ) at doses of $30 \mathrm{mg} / \mathrm{kg}$. Similarly, diclofenac $(3-30 \mathrm{mg} / \mathrm{kg}$, i.p. 30 min before acetic acid injection) dose-dependently and significantly $\left(\mathrm{F}_{3},{ }_{16}=14.50, P<0.0001\right)$ suppressed the acetic acidinduced writhes by a maximum of $87.9 \pm 10.7 \%$ (Figure $1 \mathrm{~h}$ ) at the dose of $30 \mathrm{mg} / \mathrm{kg}$. The $\mathrm{ED}_{50}$ values of drugs in the writhing test showed F32 (3.673 $\pm 0.19 \mathrm{mg} / \mathrm{kg})$ was more potent than F1 (3.687 $\pm 0.39 \mathrm{mg} / \mathrm{kg})$ was more potent than the extract $(4.176 \pm 0.34$ $\mathrm{mg} / \mathrm{kg})$. Diclofenac was however the most potent $(2.250 \pm 0.17$ $\mathrm{mg} / \mathrm{kg}$ ). The acetic acid-induced writhing test is a chemical model of nociception in which acetic acid is used as the algogenic agent. Acetic acid indirectly cause local release of endogenous proinflammatory pain mediators in peritoneal exudates and also liberates sympathetic nervous system mediators which activate peripheral nociceptive afferent neurons and also involve the local peritoneal receptors that produce the writhes (Chen et al., 2013, Sanchez-Mateo et al., 2006, Shamsi Meymandi and Keyhanfar, 2013, Roome et al., 2011, Jothimanivannan et al., 2010, Danjuma et al., 2011).The test is very sensitive and popular in detecting peripheral analgesic effect of drugs (Lin et al., 2006, Austin and Moalem-Taylor, 2013). Diclofenac (the reference analgesic drug) act by blocking the production and release of pro-inflammatory pain mediators such as prostaglandins (Higgs et al., 2013) leading to decreased abdominal writhes seen in this study. Inhibition of writhing by the extract and the fractions is therefore suggestive of peripheral analgesic action probably through inhibition of synthesis and/or release of pro-inflammatory pain mediators peripherally. Antinociception may have also occurred spinally through inhibition of pro-inflammatory pain mediators-mediated central sensitization. The presence of flavonoids and tannins among other constituents in the stem bark as reported in literature (Adamu et al., 2007, Magaji et al., 2009) might be responsible for the antinociceptive activity. These substances have been demonstrated to possess potent analgesic activities (Ching and Faloduna, 2011, Meotti et al., 2006). Besides, flavonoids potently inhibit prostaglandins, which are pro-inflammatory signaling molecules. Flavonoids also inhibit phosphodiesterase known to be involved in cell activation (Kumar et al., 2013). 
a

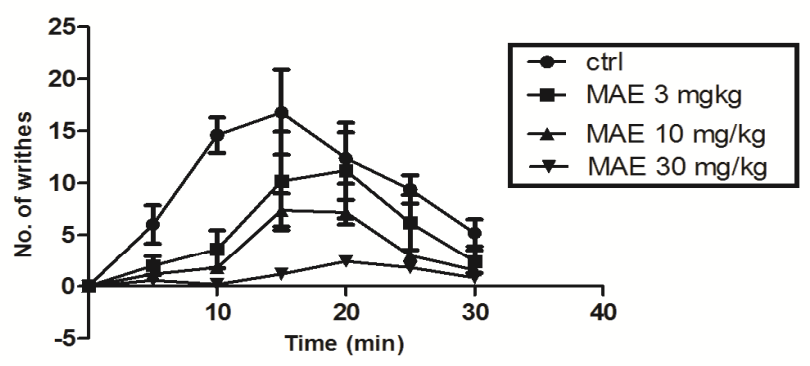

C

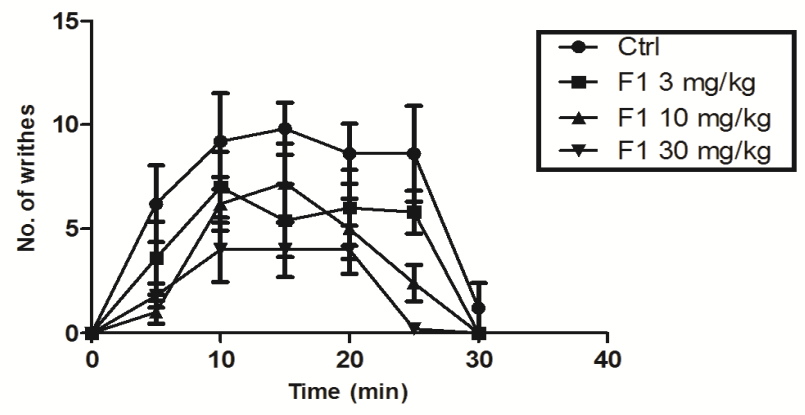

e

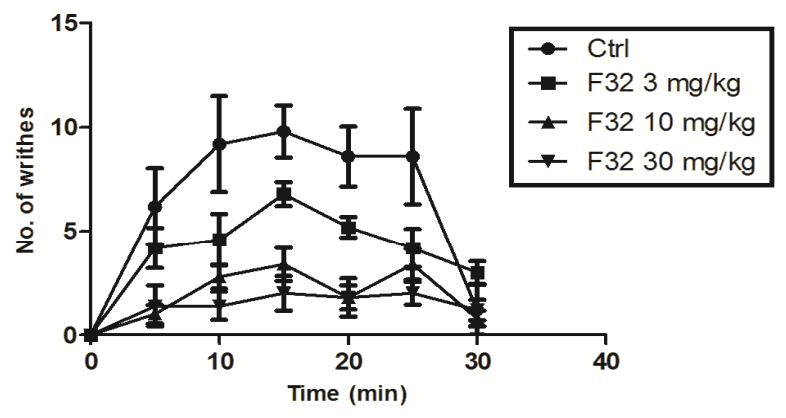

g

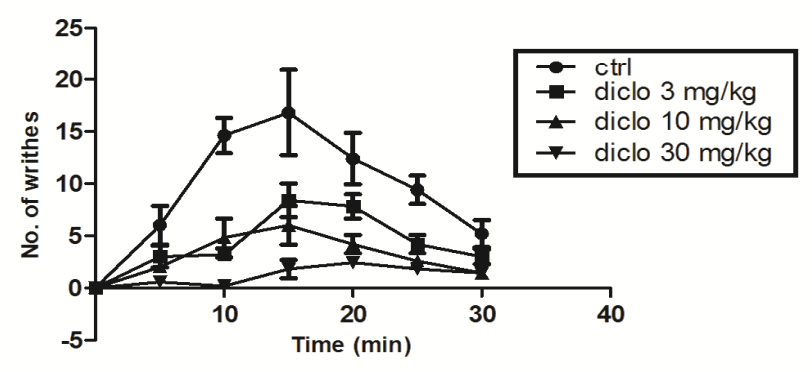

b

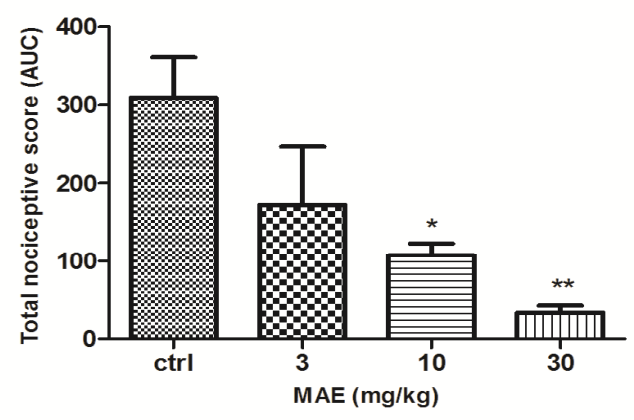

d
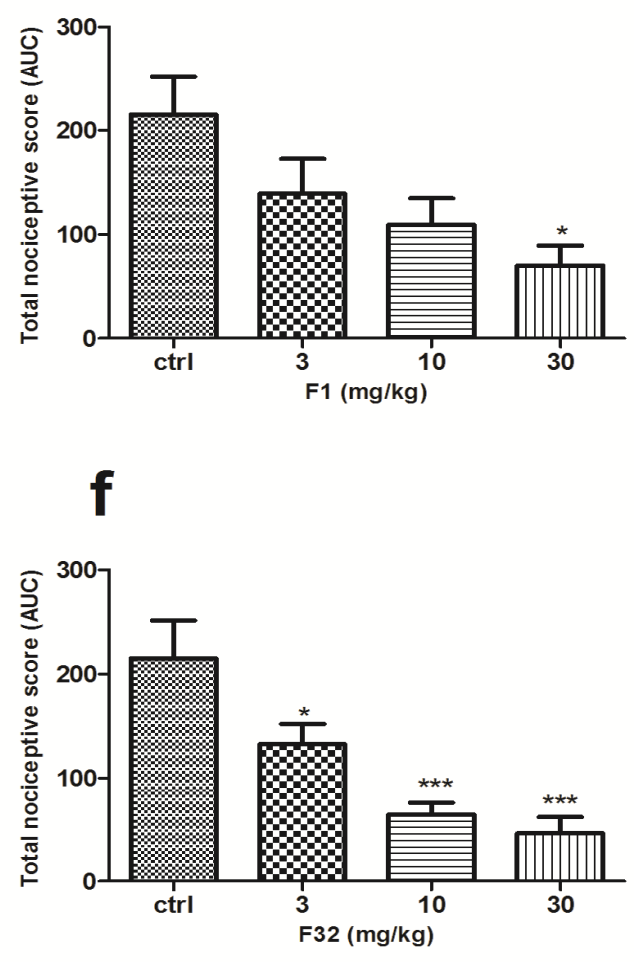

h

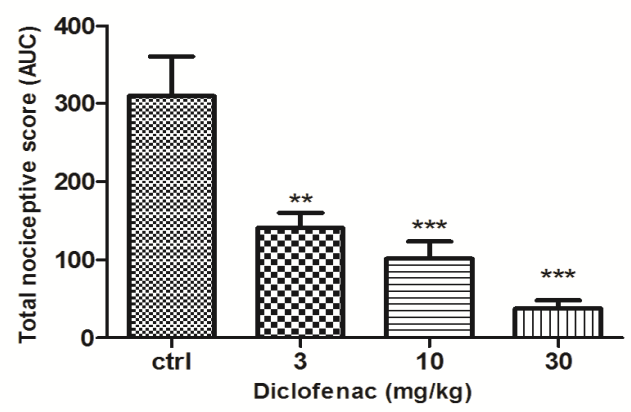

Fig. 1: Effect of MAE, F1, F32 (3- $30 \mathrm{mg} / \mathrm{kg}$, p.o.) and diclofenac (3-30 mg/kg, i.p.) on the time course curve of acetic acid-induced abdominal writhes (a, c, e and $\mathrm{g}$ ) and the total nociceptive score (calculated as AUC) (b, d, f and h) in the mice. Data are expressed as mean $\pm \operatorname{SEM}(\mathrm{n}=5) .{ }^{*} P<0.05 ;{ }^{* *} P<0.01 ;{ }^{* * *} P<0.001$ compared to vehicle-treated group (one-way ANOVA followed by Newman-Keuls post hoc test). 


\section{Evaluation of the analgesic effect of Maerua angolensis fractions in formalin test}

Injection of formalin produced a biphasic nociception which was seen more in control rats (Figure 2). Administration of F1, F32 (3 - $30 \mathrm{mg} / \mathrm{kg}$, p.o. ) and morphine $(0.1-3 \mathrm{mg} / \mathrm{kg}$, i.p. $)$ to the rats dose-dependently and significantly attenuated the timecourse curve of formalin-induced nociception when compared with the vehicle-treated group (Figure 2a, c and e). Two-way ANOVA (treatment $\mathrm{x}$ time) revealed a significant $\left(\mathrm{F} 1: \mathrm{F}_{3,208}=\right.$ 103.3, $P<0.0001 ; \mathrm{F} 32: \mathrm{F}_{3,208}=245.7, P<0.0001$ and morphine: $\mathrm{F}_{3}$, $\left.{ }_{208}=313.6, P<0.0001\right)$ effect of drug treatments on the formalininduced nociception. F1 and F32 (3-30 mg/kg, p.o. $1 \mathrm{~h}$ before formalin injection) dose-dependently and significantly suppressed paw licking time on the neurogenic $\left(\mathrm{F}_{3,16}=34.47, P<0.0001\right.$ and $\left.\mathrm{F}_{3,16}=119.5, P<0.0001\right)$ and the inflammatory $\left(\mathrm{F}_{3,16}=152.6\right.$, $P<0.0001$ and $\left.\mathrm{F}_{3,16}=1105, p<0.0001\right)$ phases over $1 \mathrm{~h}$ with maximal inhibition of the neurogenic as $92 \pm 7 \%$ and $98 \pm 2 \%$ and the inflammatory phase as $93 \pm 4 \%$ and $93 \pm 1 \%$ (Figure $2 \mathrm{~b}$ and $\mathrm{d}$ ) at doses of $30 \mathrm{mg} / \mathrm{kg}$ when compared with vehicle treated control rats. In a similar manner, morphine hydrochloride pre-treatment $(0.3-3 \mathrm{mg} / \mathrm{kg}$, i.p. $30 \mathrm{~min}$ before formalin injection) resulted into a distinct dose-dependent and significant reduction of response time in the early $\left(\mathrm{F}_{3,16}=145.1, P<0.0001\right)$ and the late $\left(\mathrm{F}_{3,16}=\right.$ $1682, P<0.0001)$ phases of formalin-induced licking with maximal inhibition of the neurogenic as $96 \pm 1 \%$ and the inflammatory phase as $97 \pm 1 \%$ (Figure $2 \mathrm{f}$ ). The calculated mean $\mathrm{ED}_{50}$ values for these effects for F1 were 1.66 and $2.46 \mathrm{mg} / \mathrm{kg}$, against the early and the late phase of the formalin response, respectively. The neurogenic-induced pain blockade by F32, occurred at 1.94 $\mathrm{mg} / \mathrm{kg}$, whereas starting from $2.18 \mathrm{mg} / \mathrm{kg}, \mathrm{F} 32$ significantly blocked pain emanating from inflammation. Formalin test is the most predictive model of acute tonic pain which assess readily both peripherally and centrally acting analgesic agents (Hunskaar and Hole, 1987, Godínez-Chaparro et al., 2013). It is also a chemical model of nociception that is popular and specific in assessing analgesic drugs. The neurogenic phase of formalin test is due to direct stimulation of transient receptor potential vanilloid 1 $\left(\mathrm{TRPV}_{1}\right)$ and transient receptor potential ankyrin $\left.1 \mathrm{TRPA}_{1}\right)$ receptors by formalin or sensitization of nociceptors by pain mediators such as substance $\mathrm{P}$ and bradykinin while the inflammatory phase is a mixture of an inflammatory reaction in the peripheral tissue and changes in central processing (Fischer et al., 2013, J Cobos and Portillo-Salido, 2013). The second phase of this test is used to predict antihyperalgesic activity of drugs in neuropathic pain models (Iliya et al., 2014, Taneja et al., 2013). The petroleum ether and ethyl acetate extracts of Maerua angolensis stem bark separately have shown analgesic activity in both phases of formalin test (Iliya et al., 2014). The fractions in this test then possibly produce their antinociception by blocking bradykinin and substance $\mathrm{P}$ peripherally or by inhibiting TRPV and $\mathrm{TRPA}_{1}$ receptors spinally in phase 1 . Analgesic action of fractions could also be due to inhibition of pro-inflammatory pain mediators centrally in phase 2 or inhibition of nociceptive effects of neurotransmitters like glutamate which act as descending pain facilitators. Analgesic effect of the fractions in the late phase of the formalin test also predicts their antihyperalgesic property in neuropathic pain models but this needs further investigations.

\section{Evaluation of the analgesic effect of Maerua angolensis extract and fractions in prostaglandin $\mathrm{E}_{\mathbf{2}}$ test}

Figure 3 shows the result obtained in the Prostaglandin $\mathrm{E}_{2}$ test. Mechanical hyperalgesia was induced in all the rats treated with prostaglandin $\mathrm{E}_{2}$ though the control group exhibited higher hyperalgesia compared to the drug treated groups. The extract, F1, F32 (3-30 mg/kg, p.o.) and morphine $(0.3-3 \mathrm{mg} / \mathrm{kg}$ i.p.) significantly (MAE: $\mathrm{F}_{3},{ }_{16}=34.39, P<0.0001, \mathrm{~F} 1: \mathrm{F}_{3},{ }_{16}=46.81$, $P<0.0001$, F32: $\mathrm{F}_{3},{ }_{16}=13.06, P<0.0005$ and morphine: $\mathrm{F}_{3},{ }_{16}=$ 25.88, $P<0.0001)$ and dose-dependently inhibited prostaglandin $\mathrm{E}_{2}$-induced mechanical hyperalgesia in rats with maximal effect at $30 \mathrm{mg} / \mathrm{kg}$ (Figure 3a, b, c and d).

This test is a selective pain test that could be more inferential to the mechanism of analgesic action of the extract and fractions. Prostaglandin $\mathrm{E}_{2}$ binds to prostanoid (EP) receptors present on peripheral terminals of sensory neurons causing sensitization of peripheral nerves to pain stimuli and hyperalgesia (measured using a mechanical source of stimulus) through activation of protein kinase A (PKA) pathway (Peng et al., 2013, St-Jacques and Ma, 2013, Lin et al., 2006, Austin and MoalemTaylor, 2013). Prostaglandin $\mathrm{E}_{2}$ also mediates an increase in nitric oxide production which is responsible for increase in vasodilatation and capillary permeability resulting to oedema and sensitization of pain fibres (Melgaard et al., 2013). The attenuation of mechanical hyperalgesia induced by prostaglandin $\mathrm{E}_{2}$ therefore suggests involvement of EP receptors or PKA pathway in the antihyperalgesic effect of the extract and fractions.

\section{Evaluation of the analgesic effect of Maerua angolensis extract and fractions in bradykinin test}

Figure 4 shows the result of the bradykinin test. Thermal hyperalgesia was induced in all the animals treated with bradykinin although the control group exhibited higher hyperalgesia compared to the drug treated groups. Administration of MAE, F1 and F32 (3 - $30 \mathrm{mg} / \mathrm{kg}$, p.o.) significantly $\left(\mathrm{F}_{3},{ }_{16}=\right.$ 12.73, $P=0.0002 ; \mathrm{F}_{3},{ }_{16}=26.38, P<0.0001$ and $\mathrm{F}_{3},{ }_{16}=20.12$, $P<0.0001$, respectively) (Figure $4 \mathrm{a}, \mathrm{b}$ and $\mathrm{c}$ ) and dose-relatedly inhibited bradykinin-induced thermal hyperalgesia in rats with maximal effect at $30 \mathrm{mg} / \mathrm{kg}$. This test is also a selective pain test that could be more inferential to the mechanisms of antinociception of the extract and fractions. Bradykinin binds to bradykinin1/bradykinin2 (B1/B2) receptors causing direct activation of protein kinase $\mathrm{C}$ (PKC) and indirect activation of PKA pathways eliciting hyperalgesia (Ferreira et al., 2004, Woode et al., 2013) which in this study was measured using a thermal source of stimulus. Bradykinin directly stimulate the Ad- and Cfibres nociceptors and may also release some pro-inflammatory mediators such as cytokines and substance $\mathrm{P}$ (Wang et al., 2008). The extract and fractions then probably produced their antinociception by blocking the activation of $\mathrm{B} 1 / \mathrm{B} 2$ receptors. 

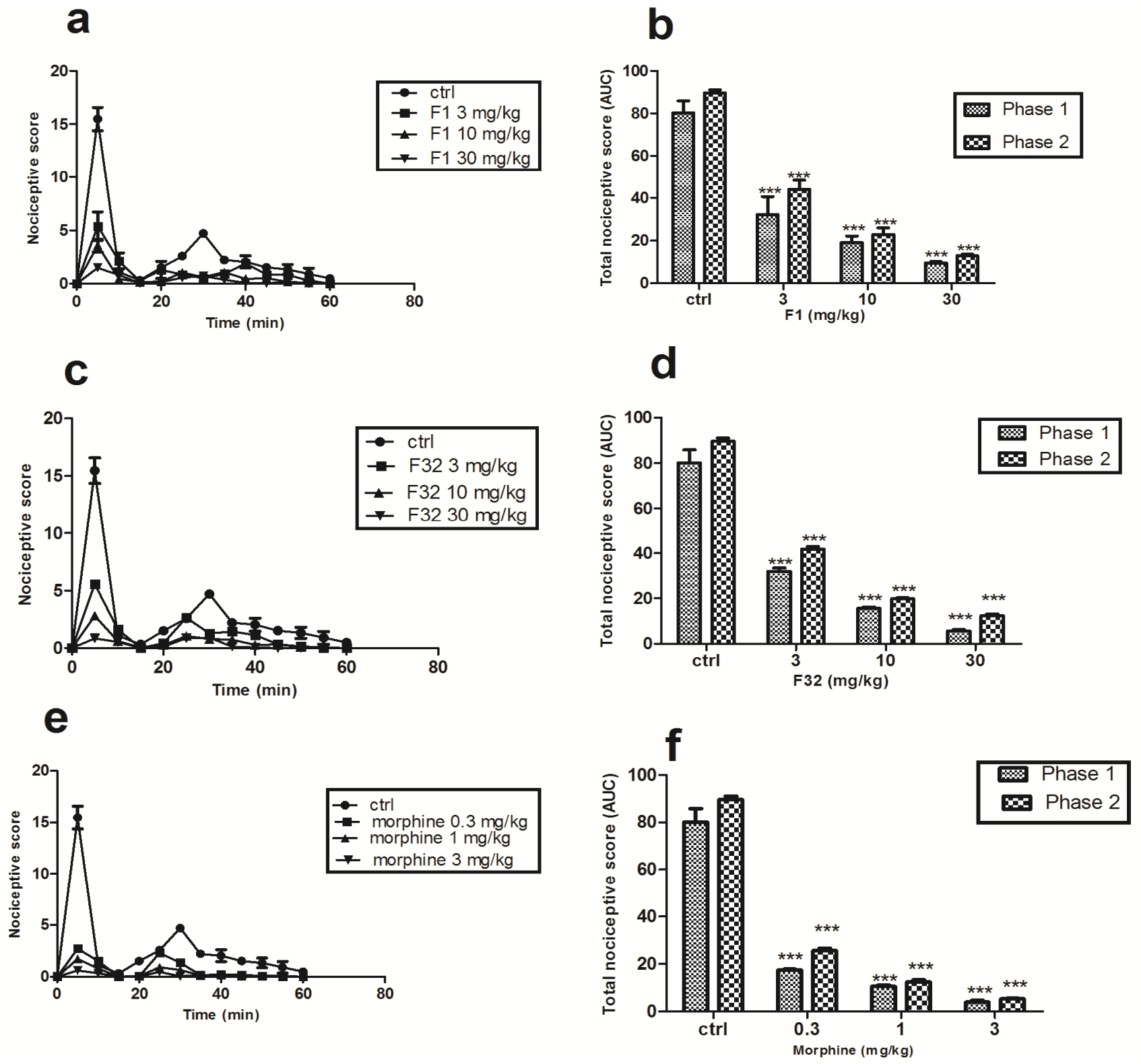

Fig. 2: Effect of F1, F32 (3-30 mg/kg, p.o.) and morphine $(0.3-3 \mathrm{mg} / \mathrm{kg}$, i.p.) on the time course curve of formalin-induced nociception (a, c and e) and the total nociceptive score (cal culated as AUC) (b, $\mathrm{d}$ and $\mathrm{f})$ in the rats. Data are expressed as mean \pm SEM $(\mathrm{n}=5) .{ }^{* * *} P<0.001$ compared to vehicle-treated group (one way ANOVA followed by Newman-Keuls post hoc test).
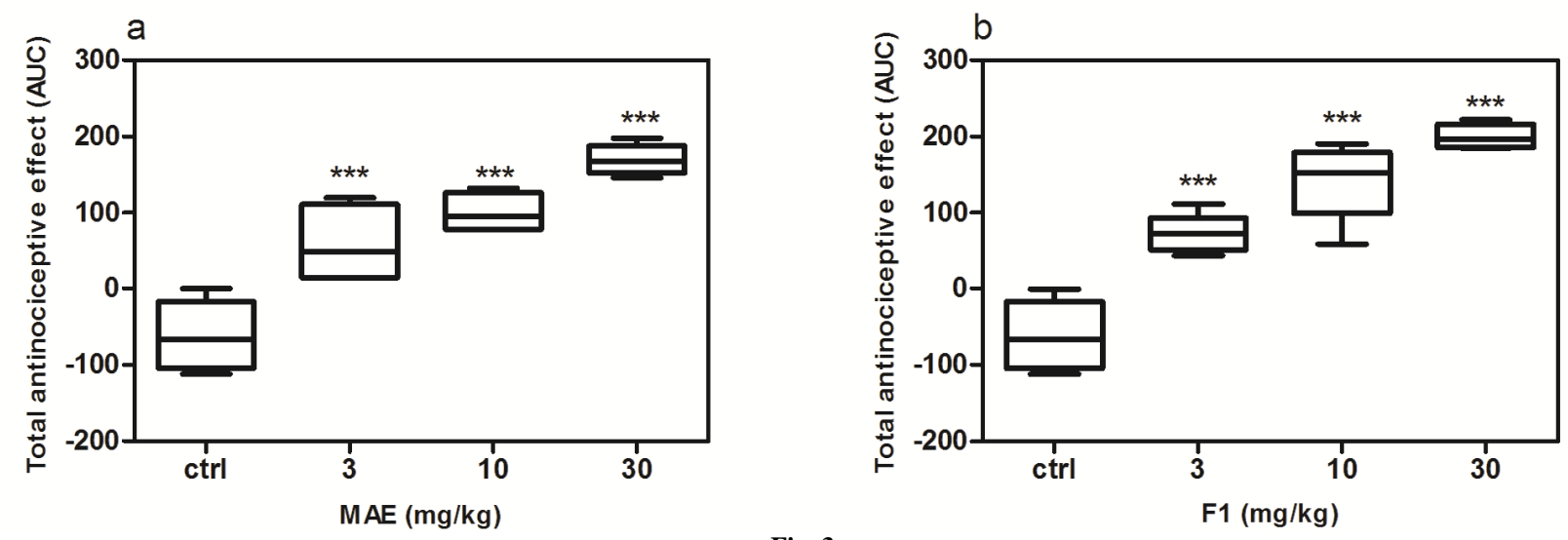

Fig. 3:... 

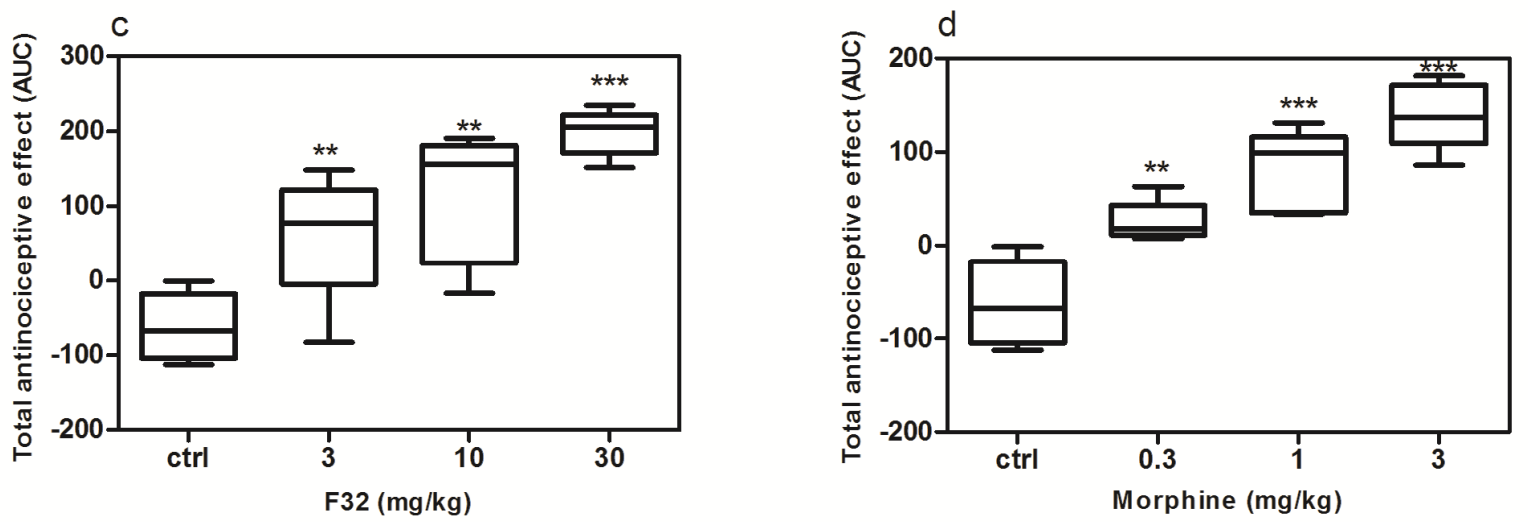

Fig. 3: Effect of MAE, F1, F32 (3- $30 \mathrm{mg} / \mathrm{kg}$, p.o.) and morphine $(0.3-3 \mathrm{mg} / \mathrm{kg}$, i.p.) on the total antinociceptive score (calculated as AUC) (a, b, c and d) of Prostaglandin E2-induced mechanical hyperalgesia in the rats. Data are expressed as mean \pm SEM $(n=5)$. The lower and upper margins of the boxes $(a, b$, $c$ and d) represent the $25^{\text {th }}$ and $75^{\text {th }}$ percentiles, with the extended arms representing the $10^{\text {th }}$ and $90^{\text {th }}$ percentiles, respectively. The median is shown as the horizontal line within the box. $* * \mathrm{P}<0.01 ; * * * \mathrm{P}<0.001$ compared to vehicle-treated group (one-way ANOVA followed by Newman-Keuls post hoc test).
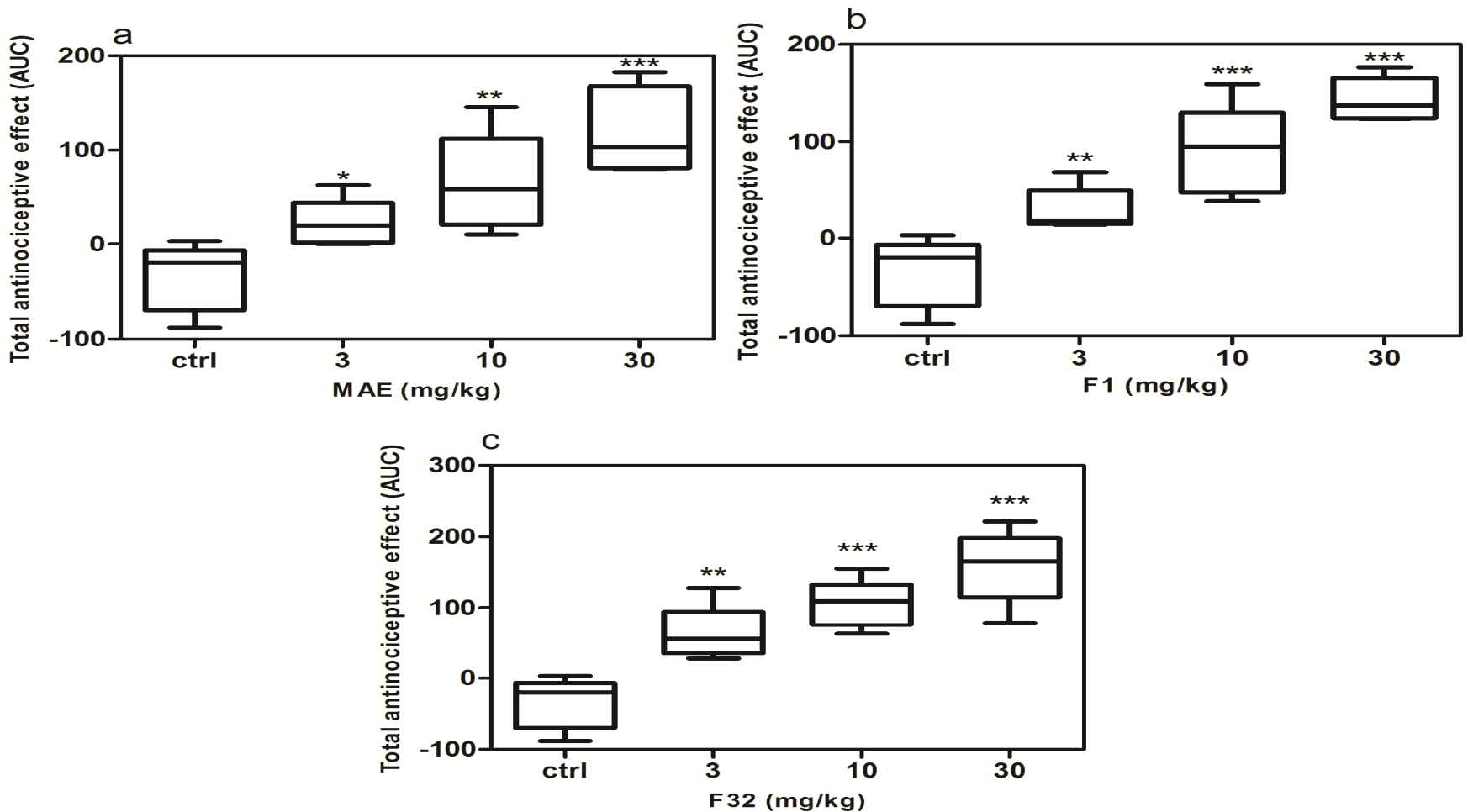

Fig. 4: Effect of MAE, F1 and F32 (3-30 mg/kg, p.o.) on the total antinociceptive score (calculated as AUC) (a, b and c) of bradykinin-induced thermal hyperalgesia in the rats. Data are expressed as mean $\pm \operatorname{SEM}(n=5)$. The lower and upper margins of the boxes $(a, b$ and $c)$ represent the $25^{\text {th }}$ and $75^{\text {th }}$ percentiles, with the extended arms representing the $10^{\text {th }}$ and $90^{\text {th }}$ percentiles respectively. The median is shown as the horizontal line within the box. $* \mathrm{P}<0.05 ; * * \mathrm{P}<0.01$; *** $\mathrm{P}<0.001$ compared to vehicle-treated group (one-way ANOVA followed by Newman-Keuls post hoc test).
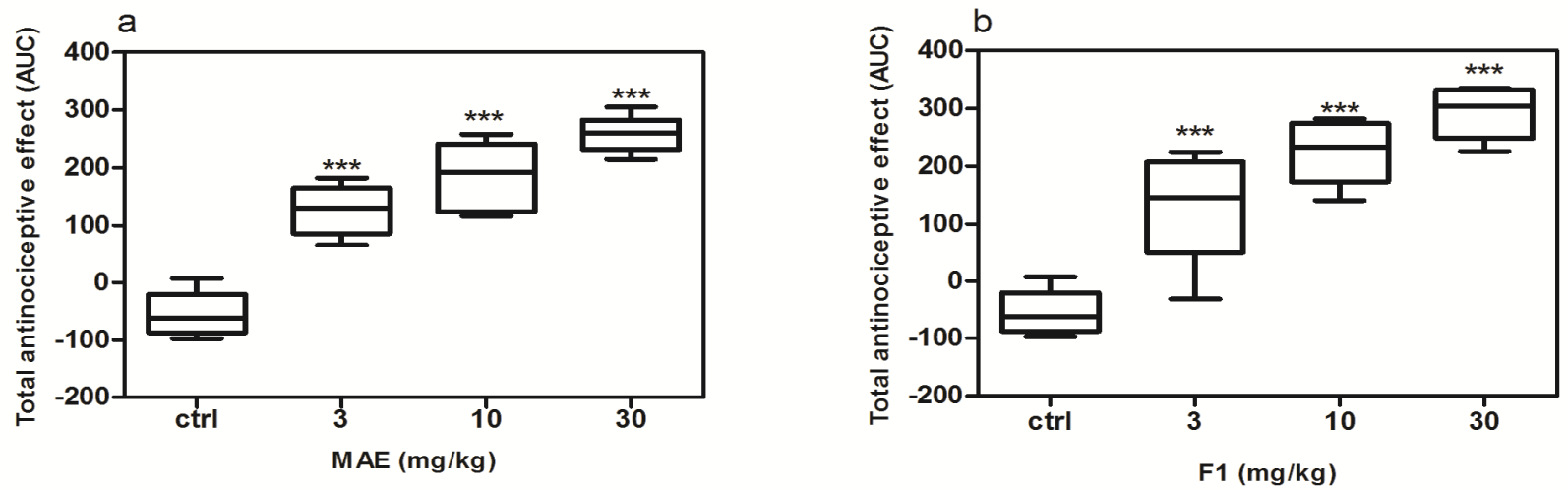

Fig. 5: ... 

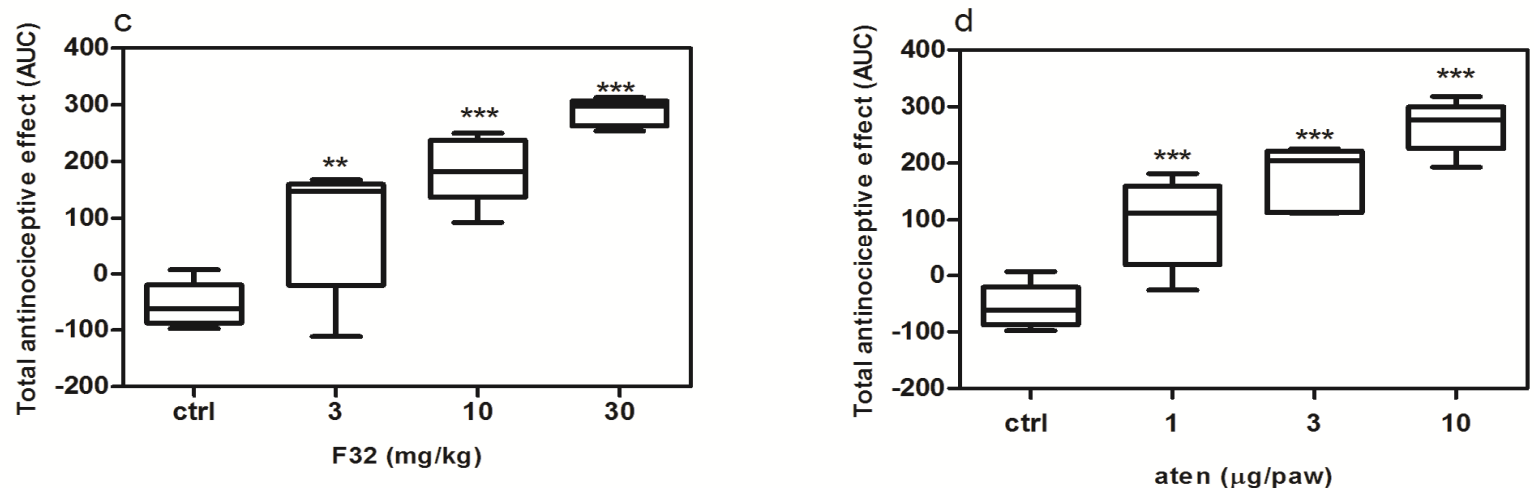

Fig. 5: Effect of MAE, F1, F32 (3 - $30 \mathrm{mg} / \mathrm{kg}$, p.o.) and atenolol $(1-10 \mu \mathrm{g} / \mathrm{paw})$ on the Total antinociceptive score (calculated as AUC) (a, b, c and d) of epinephrine-induced thermal hyperalgesia in the rats. Data are expressed as mean \pm SEM $(n=5)$. The lower and upper margins of the boxes $(a, b, c$ and $d)$ represent the $25^{\text {th }}$ and $75^{\text {th }}$ percentiles, with the extended arms representing the $10^{\text {th }}$ and $90^{\text {th }}$ percentiles, respectively. The median is shown as the horizontal line within the box. ${ }^{*} \mathrm{P}<0.01 ; * * * \mathrm{P}<0.001$ compared to vehicle-treated group (one-way ANOVA followed by Newman-Keuls post hoc test).
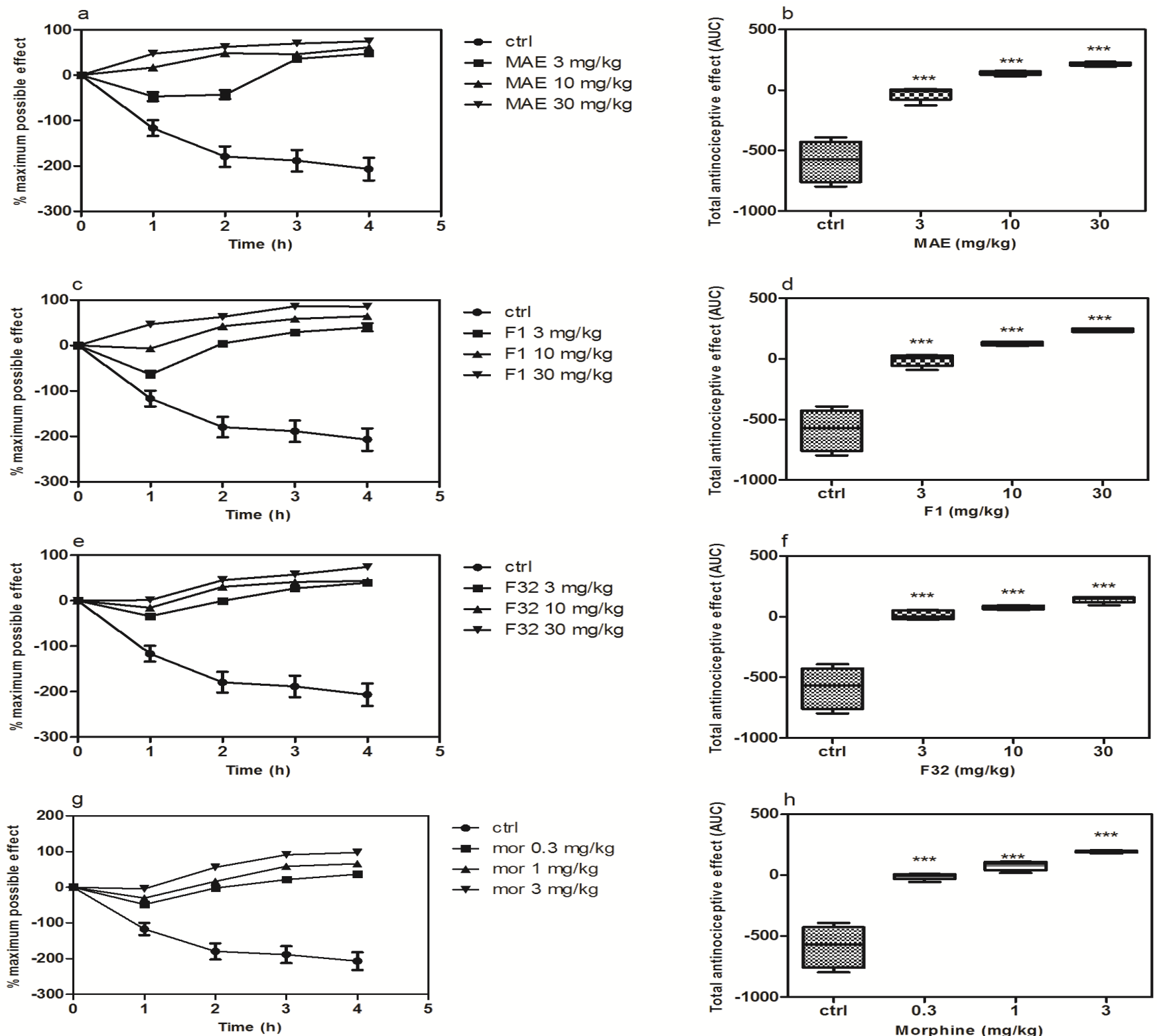

Fig. 6: Effect of MAE, F1, F32 (3 - $30 \mathrm{mg} / \mathrm{kg}$, p.o.) and morphine $(0.1-3 \mathrm{mg} / \mathrm{kg}$, i.p. $)$ on the time course curve of paw withdrawal in Hargreaves thermal hyperalgesia model (a, c, e and g) and the total antinociceptive score (calculated as AUC) $(\mathrm{b}, \mathrm{d}, \mathrm{f}$ and $\mathrm{h})$ in the rats. Data are expressed as mean \pm SEM $(\mathrm{n}=5)$. The lower and upper margins of the boxes $\left(\mathrm{b}, \mathrm{d}, \mathrm{f}\right.$ and $\mathrm{h}$ ) represent the $25^{\text {th }}$ and $75^{\text {th }}$ percentiles, with the extended arms representing the $10^{\text {th }}$ and $90^{\text {th }}$ percentiles, respectively. The median is shown as the horizontal line within the box. $* * * \mathrm{P}<0.001$ compared to vehicle-treated group (one-way ANOVA followed by Newman-Keuls post hoc test). 


\section{Evaluation of the analgesic effect of Maerua angolensis extract and fractions in epinephrine test}

Figure 5 shows that the extract, fractions and atenolol produced dose-dependent attenuation of thermal hyperalgesia when compared with the control. Pre-treatment of rats with MAE, F1, F32 (3 - $30 \mathrm{mg} / \mathrm{kg}$, p.o.) and atenolol $(1-10 \mu \mathrm{g} / \mathrm{paw})$ significantly (MAE: $\mathrm{F}_{3},{ }_{16}=44.02, P<0.0001 ; \mathrm{F} 1: \mathrm{F}_{3},{ }_{16}=27.96$, $P<0.0001 ; \mathrm{F} 32: \mathrm{F}_{3},{ }_{16}=22.24, P<0.0001$ and atenolol: $\mathrm{F}_{3},{ }_{16}=$ 28.21, $\quad P<0.0001) \quad$ inhibited epinephrine-induced thermal hyperalgesia in rats with maximal effect at $30 \mathrm{mg} / \mathrm{kg}$ (Figure $5 \mathrm{a}, \mathrm{b}$, $\mathrm{c}$ and d).

Epinephrine binds to $\beta$ adrenergic receptor to activate cyclic adenosine monophosphate/PKA independent of PKC second messenger pathways leading to hyperalgesia (Meotti et al., 2006, Woode et al., 2013). The extract and fractions then possibly inhibit $\beta$ adrenergic receptors to produce their antihyperalgesic effects.

\section{Evaluation of the analgesic effect of Maerua angolensis extract and fractions in paw withdrawal test}

Figure 6 shows the result of the paw withdrawal test using Hargreaves thermal hyperalgesia model in which paw withdrawal latency was higher for the tested drugs compared to the control group.

Two-way ANOVA (treatment $x$ time) showed doserelated reduction of carrageenan-induced thermal hyperalgesia which was significant [(MAE: $\mathrm{F}_{3,80}=323.8, P<0.0001 ; \mathrm{F} 1: \mathrm{F}_{3,80}=$ $335.8, P<0.0001 ; \mathrm{F} 32: \mathrm{F}_{3,80}=296.6, P<0.0001$; morphine: $\mathrm{F}_{3,80}=$ 320.3, $P<0.0001$ ) (Figure 6a, c, e and g)]. MAE, F1, F32 and morphine produced significant (MAE: $\mathrm{F}_{3},{ }_{16}=81.06, P<0.0001$; $\mathrm{F} 1: \mathrm{F}_{3},{ }_{16}=84.61, P<0.0001 ; \mathrm{F} 32: \mathrm{F}_{3},{ }_{16}=72.21, P<0.0001$ and morphine: $\mathrm{F}_{3},{ }_{16}=77.34, P<0.0001$ ) (Figure $6 \mathrm{~b}, \mathrm{~d}, \mathrm{f}$ and $\mathrm{h}$ ) and dose-dependent reduction in thermal hyperalgesia.

This test is used to detect central analgesic activity of drugs and has selectivity for opioid-derived analgesics (Taïwe $e t$ al., 2011, Gupta et al., 2013, Spetea, 2013). Moreover, it has since been demonstrated that activation of the mu-opioid receptors mediates antinociceptive effects (Jaremko et al., 2014). The extract and fractions thus probably exerts central antinociception via activation of opioid receptors.

\section{Evaluation of motor performance in the analgesic effect of Maerua angolensis extract and fractions}

Table 1 shows the time of mice stay on the rotating bar in the rotarod test. MAE, F1 and F32 at 1, 2, 3, and $4 \mathrm{~h}$ after oral administration did not significantly alter the motor response of the mice at the dose of $3-10 \mathrm{mg} / \mathrm{kg}$; however, significantly affect the motor response of the animals at the highest dose $(30 \mathrm{mg} / \mathrm{kg})$ when compared with animals that received normal saline. The control response in the rotarod test was $95.24 \pm 0.14$ verse $94.36 \mathrm{~s}$ in the presence of $\operatorname{MAE}\left(\mathrm{F}_{3},{ }_{16}=4.503, P=0.0179\right) ; \mathrm{F} 1\left(\mathrm{~F}_{3},{ }_{16}=5.046\right.$, $P=0.0119)$ and $\mathrm{F} 32\left(\mathrm{~F}_{3}, 16=5.705, P=0.0075\right)$. This test is used to assess impairment of motor function in the antinociception of drugs and is useful in complementing models such as writhing test which is non-specific for evaluating antinociceptive effects of drugs since drugs like muscle relaxants used as adjuvant in pain management show analgesic effect in this model (Pietrovski et al., 2006). The extract and fractions then at $3-10 \mathrm{mg} / \mathrm{kg}$ produce antinociception without impairing motor function.

Table 1: Effect of the oral treatment of the petroleum ether/ethyl acetate extract and the fractions prepared from the stem barks of Maerua angolensis on motor performance of mice in the rotarod test.

\begin{tabular}{ccc}
\hline Treatment & Dose $(\mathbf{m g} / \mathbf{k g})$ & Time in the rotating bar $(\mathbf{s})$ \\
\hline Normal saline & - & $95.24 \pm 0.14$ \\
MAE & 3 & $94.60 \pm 0.25$ \\
MAE & 10 & $94.52 \pm 0.31$ \\
MAE & 30 & $94.12 \pm 0.10^{* *}$ \\
F1 & 3 & $94.66 \pm 0.25$ \\
F1 & 10 & $94.52 \pm 0.31$ \\
F1 & 30 & $94.12 \pm 0.10^{* *}$ \\
F32 & 3 & $94.38 \pm 0.18$ \\
F32 & 10 & $94.42 \pm 0.38$ \\
F32 & 30 & $93.86 \pm 0.19^{* *}$
\end{tabular}

MAE: Maerua angolensis extract; F1: Maerua angolensis fraction 1; F32: Maerua angolensis fraction 32. Data are expressed as mean \pm SEM of the total time spent on the rotating bar during a 2 min test, $\mathrm{n}=5$ animals. Data were analysis by one-way ANOVA, followed by Newman-Keuls post hoc test.

${ }^{* *} P<0.01$, significantly different compared to the vehicle-treated group.

\section{CONCLUSION}

The petroleum ether/ethyl acetate extract and fractions obtained from stem bark of Maerua angolensis possesses both peripheral and central antinociceptive effects in the animal models of chemical, mechanical and thermal nociception. This support the traditional use of the plant in the treatment of pain, and so can be exploited for development in therapy. Further studies are in progress to elucidate the mechanisms of the observed effects.

\section{REFERENCES}

Adamu A, Abdurahman E, Ibrahim H, Abubakar M, Magaji M, Yaro A. Effect of aqueous methanolic stem bark extract of Maerua angolensis DC on acute and sub-acute inflammations. Nig J Pharm Sci, 2007; 6:1 - 6 .

Austin P, Moalem-Taylor G. 2013. Pathophysiology of neuropathic pain: inflammatory mediators. In: Toth $\mathrm{C}$, Moulin DE, ed. Neuropathic Pain: Causes, Management and Understanding. Cambridge UK: Cambridge University Press $77-89$

Chen L, Yang G, Grosser T. Prostanoids and inflammatory pain. Prostaglandins Other Lipid Mediat, 2013; 104:58-65.

Ching FP, Faloduna A. Dimethoxyflavone, a flavonoid from Stereospermum kunthianum stem bark with analgesic and anti inflammatory activities. West Afr J Pharmacol Drug Res, 2011; 27:16 20 .

Danjuma NM, Sani AA, Yaro AH, Ahmad A, Zezi AU, Hussani IM. Preliminary evaluation of methanolic leaf extract of Burkea africana Linn for analgesic, anti-inflammatory and antioxidant effects. J Pharmacol Tropical Ther, 2011; 2:7 - 11.

Fecho K, Nackley AG, Wu Y, Maixner W. Basal and carrageenan-induced pain behavior in Sprague-Dawley, Lewis and Fischer rats. Physiol Behav, 2005; 85:177-186.

Ferreira J, Da Silva GL, Calixto JB. Contribution of vanilloid receptors to the overt nociception induced by $\mathrm{B} 2$ kinin receptor activation in mice. Br J Pharmacol, 2004; 141:787-794. 
Fischer MJ, Btesh J, McNaughton PA. Disrupting sensitization of transient receptor potential vanilloid subtype 1 inhibits inflammatory hyperalgesia. J Neurosci, 2013; 33:7407-7414.

Galbraith JA, Mrosko BJ, Myers RR. A system to measure thermal nociception. J Neurosci Methods, 1993; 49:63-68.

Gareri P, Condorelli D, Belluardo N, Citraro R, Barresi V, Trovato-Salinato A, Mudo G, Ibbadu GF, Russo E, De Sarro G. Antiabsence effects of carbenoxolone in two genetic animal models of absence epilepsy (WAG/Rij rats and $\mathrm{Ih} / \mathrm{Ih}$ mice). Neuropharmacology, 2005; 49:551-563.

Godínez-Chaparro B, López-Santillán FJ, Argüelles CF, Villalón CM, Granados-Soto V. Role of 5-HT receptors in the reduction of formalin-induced nociception and secondary allodynia/hyperalgesia produced by antimigraine drugs in rats. Life Sci, 2013; 92:1046-1054.

Gupta M, Banerjee D, Mukherjee A. Evaluation of analgesic, antipyretic and anti-inflammatory effects of methanol extract of traditional herbal medicine using rodents. J Pharmacogn Phytother, 2013; 5:106-113.

Higgs J, Wasowski C, Loscalzo LM, Marder M. In vitro binding affinities of a series of flavonoids for $\mu$-opioid receptors. Antinociceptive effect of the synthetic flavonoid 3, 3-dibromoflavanone in mice. Neuropharmacology, 2013; 72:9 - 19.

Hunskaar S, Hole K. The formalin test in mice: dissociation between inflammatory and non-inflammatory pain. Pain, 1987; 30:103 114

Iliya HA, Boakye-Gyasi E, Adongo WD, Ampadu FA, Woode E. Antinociceptive activity of various solvent extracts of Maerua angolensis DC stem bark in rodents. Phytopharmacology, 2014; 13:1 - 8.

J Cobos E, Portillo-Salido E. "Bedside-to-Bench" Behavioral Outcomes in Animal Models of Pain: Beyond the Evaluation of Reflexes. Curr Neuropharmacol, 2013; 11:560-591.

Jaremko KM, Thompson NL, Reyes BA, Jin J, Ebersole B, Jenney CB, Grigson PS, Levenson R, Berrettini WH, Van Bockstaele EJ. Morphine-induced trafficking of a mu-opioid receptor interacting protein in rat locus coeruleus neurons. Prog Neuro-Psychopharmacol Biol Psychiatry, 2014; 50:53-65.

Jothimanivannan C, Kumar R, Subramanian N. Antiinflammatory and analgesic activities of ethanol extract of aerial parts of Justicia gendarussa Burm. Int J Pharmacol, 2010; 6:278-283.

Kondo M, Gray LJ, Pelka GJ, Christodoulou J, Tam PP, Hannan AJ. Environmental enrichment ameliorates a motor coordination deficit in a mouse model of Rett syndrome-Mecp2 gene dosage effects and BDNF expression. Eur J Neurosci, 2008; 27:33423350 .

Kumar N, Goldminz AM, Kim N, Gottlieb AB. Phosphodiesterase 4-targeted treatments for autoimmune diseases. BMC Med, 2013; 11:96 - 104.

Lin CR, Amaya F, Barrett L, Wang H, Takada J, Samad TA, Woolf CJ. Prostaglandin E2 receptor EP4 contributes to inflammatory pain hypersensitivity. J Pharmacol Exp Ther, 2006; 319:1096 - 1103.

Magaji MG, Yaro AH, Adamu A, Yau J, Malami S, Abubakar Y, Hussaini IM. Some neuropharmacological studies on hydroalcoholic extract of Maerua angolensis DC (capparidaceae) in mice and chicks. Int J Pure and Appl Sci, 2009; 3:14 - 21.

Magaji MG, Yaro AH, Maiha BB, Maje IM, Musa AM. Preliminary gastrointestinal studies on aqueous methanolic stem bark extract of Maerua angolensis (capparidaceae). Nig J Pharm Sci, 2008; 7:108 - 113 .

Meda N, Bangou M, Bakasso S, Millogo-Rasolodimby J, Nacoulma O. Antioxidant activity of phenolic and flavonoid fractions of Cleome gynandra and Maerua angolensis of Burkina Faso. J Appl Pharm Sci, 2013; 3:36- 42 .

Melgaard L, Hersini KJ, Gazerani P, Petersen LJ. Retrodialysis: a review of experimental and clinical applications of reverse microdialysis in the skin. Skin Pharmacol Physiol, 2013; 26:160-174.

Meotti FC, Luiz AP, Pizzolatti MG, Kassuya CA, Calixto JB, Santos AR. Analysis of the antinociceptive effect of the flavonoid myricitrin: evidence for a role of the L-arginine-nitric oxide and protein kinase C pathways. J Pharmacol Exp Ther, 2006; 316:789 - 796.
Mohammed A, Tanko Y, Okasha MA, Sadiq Y, Isa AL. Effect of aqueous methanolic stem bark of Maerua angolensis (capparidaceae) extract on blood glucose levels of streptozocin-induced diabetic wistar rats. Res J Pharmacol, 2008; 1:75 - 78.

Moriyama T, Higashi T, Togashi K, Lida T, Segi E, Sugimoto Y, Tominaga T, Narumiya S, Tominaga M. Sensitization of TRPV1 by EP1 and IP reveals peripheral nociceptive mechanism of prostaglandins. Mol pain, 2005; 1:3 - 15.

Mothana RA, Lindequist U, Gruenert R, Bednarski PJ. Studies of the in vitro anticancer, antimicrobial and antioxidant potentials of selected Yemeni medicinal plants from the island Soqotra. BMC Complement Altern Med, 2009; 9:7 - 17.

Negus SS, Vanderah TW, Brandt MR, Bilsky EJ, Becerra L, Borsook D. Preclinical assessment of candidate analgesic drugs: recent advances and future challenges. J Pharmacol Exp Ther, 2006; 319:507514.

Okatch H, Ngwenya B, Raletamo KM, Andrae-Marobela K. Determination of potentially toxic heavy metals in traditionally used medicinal plants for HIV/AIDS opportunistic infections in Ngamiland District in Northern Botswana. Analytica Chimica Acta, 2012; 730:42-48

Peng Y, Shi J, Du X, Wang L, Klocker H, Mo L, Mo Z, Zhang J. Prostaglandin E2 induces stromal cell-derived factor-1 expression in prostate stromal cells by activating protein kinase A and transcription factor Sp1. Int J Biochem Cell Biol, 2013; 45:521-530.

Pietrovski EF, Rosa KA, Facundo VA, Rios K, Marques MCA, Santos AR. Antinociceptive properties of the ethanolic extract and of the triterpene $3 \beta, 6 \beta, 16 \beta$-trihidroxilup-20 (29)-ene obtained from the flowers of Combretum leprosum in mice. Pharmacol Biochem Behav, 2006; 83:90 -99 .

Porth C. 2011. Essentials of pathophysiology: Concepts of altered health states. London, UK: Lippincott Williams \& Wilkins.

Randall LO, Selitto JJ. A method for measurement of analgesic activity on inflamed tissue. Arch Int Pharmacodyn Ther, 1957; 111:409419.

Roome T, Dara A, Naqvi S, Choudhary MI. Evaluation of antinociceptive effect of Aegiceras corniculatum stems extracts and its possible mechanism of action in rodents. J Ethnopharmacol, 2011; 135:351 - 358 .

Sanchez-Mateo CC, Bonkanka CX, Hernandez-Perez M, Rabanal RM. Evaluation of the analgesic and topical anti-inflammatory effects of Hypertcum reflexum L. fil. J Ethnopharmacol, 2006; 107:1 - 6. 2004; 4:S4-S18

Schim JD, Stang P. Overview of pain management. Pain Pract,

Shamsi Meymandi M, Keyhanfar F. Assessment of the antinociceptive effects of pregabalin alone or in combination with morphine during acetic acid-induced writhing in mice. Pharmacol Biochem Behav, 2013; 110:249-254.

Sikdar A, Biswas A, Bhattacharya S, Biswas M. Assessment of analgesic activity of Pterocarpus marsupium leaf extracts in Swiss albino mice. J Adv Pharm Educ Res, 2013; 3:42 - 45.

Spetea M. Opioid receptors and their ligands in the musculoskeletal system and relevance for pain control. Curr Pharm Des, 2013; 19:7382-7390.

St-Jacques B, Ma W. Prostaglandin E2/EP4 signalling facilitates EP4 receptor externalization in primary sensory neurons in vitro and in vivo. Pain, 2013; 154:313-323.

Taïwe GS, Bum EN, Talla E, Dimo T, Weiss N, Sidiki N, Dawe A, Okomolo Moto FC, Dzeufiet PD, Waard MD. Antipyretic and antinociceptive effects of Nauclea latifolia root decoction and possible mechanisms of action. Pharm Biol 2011; 49:15 - 25.

Tanabe M, Takasu K, Kasuya N, Shimizu S, Honda M, Ono H. Role of descending noradrenergic system and spinal $\alpha 2$-adrenergic receptors in the effects of gabapentin on thermal and mechanical nociception after partial nerve injury in the mouse. Br J Pharmacol, 2005; 144:703-714.

Taneja A, Troconiz I, Danhof M, Della Pasqua O. Semimechanistic Modelling of the Analgesic Effect of Gabapentin in the 
Formalin-Induced Rat Model of Experimental Pain. Pharm Res, 2013; $31: 593-606$

Tjølsen A, Berge OG, Hunskaar S, Rosland JH, Hole K. The formalin test: an evaluation of the method. Pain, 1992; 51:5 - 17.

Wang S, Dai Y, Fukuoka T, Yamanaka H, Kobayashi K, Obata K, Cui X, Tominaga M, Noguchi K. Phospholipase C and protein kinase A mediate bradykinin sensitization of TRPA1: a molecular mechanism of inflammatory pain. Brain, 2008; 131:1241-1251.

Wilhelm EA, Jesse CR, Bortolatto CF, Nogueira CW, Savegnago L. Antinociceptive and anti-allodynic effects of 3-alkynyl selenophene on different models of nociception in mice. Pharmacol Biochem Behav, 2009; 93:419-425.

Woode E, Ameyaw E, Ainooson G, Abotsi W, Gyasi E, Kyekyeku J. Analgesic Effects of an Ethanol Extract of the Fruits of Xylopia aethiopica and Xylopic Acid in Murine Models of Pain: Possible Mechanism (s). Pharmacologia, 2013; 4:285-300.
Woode E, Boakye-Gyasi E, Ainooson G, Ansah C, Duwiejua M. Anti-Nociceptive Effects and the Mechanism of Palisota hirsuta K. Schum. Leaf Extract in Murine Models. Int J Pharmacol, 2009; 55:101 113.

\section{How to cite this article:}

Hosea Azi Iliya, Eric Woode., Evaluation of Analgesic Property of Petroleum Ether/Ethyl Acetate Stem Bark Extract and Fractions of Maerua angolensis in Murine Models of Pain. J App Pharm Sci, 2015; 5 (02): 091-102. 